\section{Földhasználat, vízgazdálkodás}

\author{
Nagy János \\ Debreceni Egyetem Agrár- és Gazdálkodástudományok Centruma, \\ Mezőgazdaság-, Élelmiszertudományi és Környezetgazdálkodási Kar, \\ Földhasznosítási, Müszaki és Területfejlesztési Intézet, Debrecen \\ nagyjanos@agr.unideb.hu
}

ÖSSZEFOGLALÁS

A világ növénytermesztésének - a 2050-re tervezett 9,2 milliárd népessége miatt - nincs más választása, mint a termelés növelése. Ez óriási kihivást jelent a mezögazdaság számára. Az elörejelzések szerint ugyanis a termelés növekedési üteme a föbb gabonaféléknél a termöföld, a víz, a növekvö üzemanyag-és mütrágya árak, továbbá az éghajlatváltozás hatásainak köszönhetöen csökken. A növénytermesztés leghatékonyabb módját a preciziós mezögazdaság jelenti. Alkalmazni kell a minimális talajmüvelést, amely védi a talajfelszint és a nedvesség megtartása mellett, növeli a talaj vízbefogadó képességét. A mütrágya, vetömag, öntözés, növényvédöszer helyspecifikus felhasználása mellett a táblán belüli, területi felvételezéseken alapuló célzott kijuttatása is számításba vehetö. Az új technológia alkalmazása jelentős költségmegtakaritást eredményez, illetve csökkenti a környezetterhelést.

Kulcsszavak: népesség, élelmiszertermelés, földhasználat, klimaváltozás, öntözés

\section{SUMMARY}

Due to the prognosed population increase to 9.2 billion people by 2050, the world's crop production does not have any other chance than to increase production. This demand is a huge challenge for agriculture. Based on the forecasts, the growth rate of production of the main cereals will decrease as a result of the effect of soil, water, the increasing fuel and fertiliser prices and the impacts of climate change. Methods ensuring sustainability have to be preferred. Precision agriculture is the most effective method of crop production. We have to apply minimum cultivation in order to protect the soil surface, maintain its moisture content and increase its water reception ability. In addition to the localised use of fertiliser, sowing seed, irrigation and pesticides, it is also important to apply them in a targeted way on the basis of plot imaging. The use of the new technology results in significant cost saving and it could also reduce environmental load.

Keywords: population, food production, land use, climate change, irrigation

\section{BEVEZETÉS}

Az elmúlt évtizedekben a világ növénytermesztése jelentős változáson ment keresztül. A mezőgazdaságban a „Zöld forradalom” az 1960-as években (becslések szerint) egy milliárd embert mentett meg az éhínségtől. A változás a magas hozamú növényfajtáknak, az öntözésnek, a növényvédőszerek és a modern technikák alkalmazásának volt köszönhetö.

A népesség növekedése miatt egyre nagyobb a kereslet a mezőgazdasági termékek iránt és ez szükségessé teszi a mezőgazdasági földterületek bővítését. A jelenlegi mezőgazdasági gyakorlat azonban hozzájárul a negatív környezeti hatásokhoz, mint például az éghajlatváltozás, a biológiai sokféleség csökkenése, a víz-és levegőszennyezés, talaj erózió. Annak érdekében, hogy a termelés úgy növekedjen, hogy a környezeti terhelés csökkenjen a $\mathrm{K}+\mathrm{F}+\mathrm{I}$ tevékenység, a kereslet és a termelési oldal összhangjára van szükség.

\section{NÉPESSÉG}

1950-ben a világon 2,5 milliárd és 2005-ben 6,5 milliárd ember élt. 2050-re ez a szám meghaladhatja a 9 milliárdot (ENSZ, 2006). Az éves növekedési ütem csúcspontja 1963-ban volt, amikor elérte 2,19\%-ot. 2005-re a növekedés mértéke majdnem a felére csökkent $(1,1 \%)$, kb. 75 millió ember évente. Ez a növekedési ütem várhatóan tovább csökken a következő években, a jelenlegi becslések szerint 2020-ra kevesebb lesz, mint 1\%, 2050-re pedig kevesebb, mint 0,5\%. Ez azt jelenti, hogy a világ népessége tovább fog növekedni a 21. században, de lassabb ütemben, mint az elmúlt időszakban. A világ népessége megduplázódott (100\%-os növekedés) 40 éven belül (1959-ben 3 milliárd és 1999-ben 6 milliárd. A jelenlegi becslések szerint további 42 év szükséges ahhoz, hogy további 50\%-kal növekedjen a népesség, 2042-re éri el a 9 milliárdot. A legmagasabb népességnövekedésre Ázsiában és Afrikában lehet számítani, 2050-ben a világ népességének közel $86 \%$-a fog ezeken a területeken élni, míg Európában csökkenni fog a népesség.

Magyarország népessége 9 millió 982 ezer fö volt 2011-ben, ez 2,1\%-kal kevesebb, mint a 2001-es népszámlálás alkalmával. Az ország népessége 1981 óta folyamatosan csökken, legnagyobb mértékben az 1980-as években, majd a csökkenés mértéke mérséklödött, és 2001-2011 között ismét fokozódott. 2050-re az elörejelzések szerint - 9 millió 200 ezerre lesz tehető az ország népessége (1. ábra).

\section{ÉLELMISZERTERMELÉS, ÉHEZÉS}

Növénytermesztést 1400 millió hektár szántóterületen folytatnak a világon. A legfontosabb 15 kultúrnövény (búza, rizs, kukorica, árpa, köles, szemescirok, szójabab, gyapot, zab bab, burgonya, földimogyoró, rozs, édesburgonya és cukornád) közül 8 a gabonanövények csoportjába tartozik, ezek együttes vetésterülete 700-710 millió ha.

A világ gabonatermesztését a zöld forradalom (1950-1985) időszakában közel három és félszeresére sikerült növelni. Ezt az eredményt a nagymértékü inputok (műtrágyázás, öntözés, gépesített talajmüvelés, növénynemesítés, és a vegyszeres növényvédőszerek) felhasználásával érték el (2.ábra). A növekedés üteme az elmúlt évtizedben jelentősen csökkent. 
1. ábra: Magyarország népességének alakulása (1970-2050)

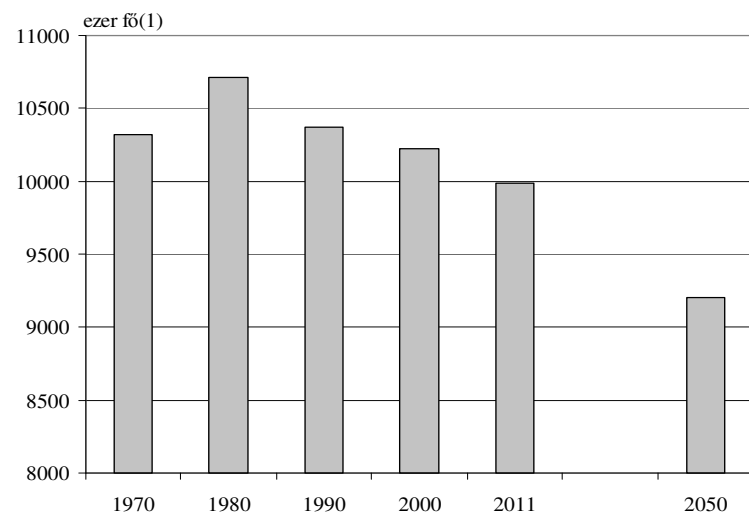

Forrás: KSH, 1970-2011; ENSZ, 2011 adatok alapján saját szerkesztés

Figure 1: The population of Hungary 1970-2050)

Thousand people(1), Source: CSO, 1970-2011; UN, own edition based on 2012 data

\section{2. ábra: A világ föbb gabonanövényeinek termésmennyisége} (1960-2010)

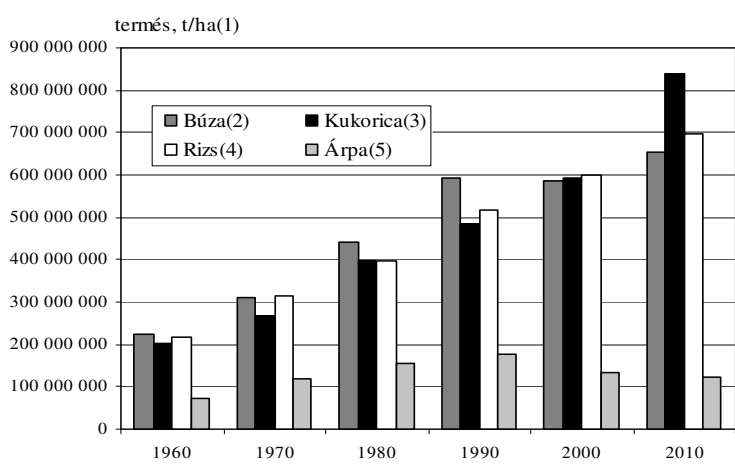

Forrás: FAOSTAT, 1960-2010 adatok alapján saját szerkesztés

Figure 2: Yield of the main cereals in the world (1960-2010) Yield t ha' ${ }^{-1}(1)$, Wheat(2), Maize(3), Rice(4), Barley(5), Source: FAOSTAT, own edition based on 1960-2010 data

Magyarországon a búza termőterülete a 2000-2011 közötti időszak átlagában 1,097 millió hektár volt; a szélső értéket a 2011. év (978 millió hektár) és a 2004. év (1,174 millió hektár) képviselte. Ugyanezen időszakban a betakarított búza mennyisége átlagosan 4,425 millió tonnát tett ki; szélsőséges volt a rendkívül aszályos 2003. év (2,941 millió tonna) és a rákövetkező 2004. év (6,007 millió tonna). 2011-ben 978 millió hektáron aratták le a búzát, erről 4,107 millió tonna termény került a raktárakba.

A búza élelmezési és takarmányozási célú felhasználása évente mintegy 2,6-2,8 millió tonnára tehető. $\mathrm{E}$ két területen a felhasználás számottevő változása nem valószínüsíthető a jövőben. A belföldi felhasználáson túl évente átlagosan 1-2 millió tonna közötti többletmennyiség áll rendelkezésre, amit az export adatai is tükröznek.

A kukorica hazánkban évtizedek óta a legnagyobb területen termesztett kultúra. Vetésterülete stabil, 2000 2011 közötti időszak átlagában 1,180 millió hektár volt, a szélső értéket az aszályos 2007. év (1,079 millió hektár) és a 2001. év (1,258 millió hektár) mutatott.
Ugyanezen időszakban a betakarított kukorica mennyisége 7,049 millió tonna volt a 2005. évi (9,050 millió tonna) és a 2007. évi (4,027 millió tonna) szélső értékekkel. 2007-ben az elvetett kukorica közel 14\%-a semmisült meg a virágzási időszakban fellépő vízhiány miatt. Az országos átlagtermés az utóbbi évek egyik leggyengébb eredményének számított, csak 3,7 t/ha értéket ért el. A kedvező időjárás következtében 2008ban duplája volt a hektáronkénti átlagtermés $(7,4 \mathrm{t} / \mathrm{ha})$ az egy évvel korábbinak. 2011-ben az 1,230 millió hektár kukoricaterületről 7,992 millió tonna termény került a raktárakba.

A világon 1 milliárd ember éhezik és 25 ezren halnak meg éhen, miközben 1,3 milliárd tonna étel kerül hulladékba, ami több mint a világ gabonatermelésének 50\%-a (3. ábra). Magyarországon évente kb. 100 ezer embernek, köztük 10 ezer gyereknek nem jut elegendő élelem.

3. ábra: A világ éhezőinek száma (2010)

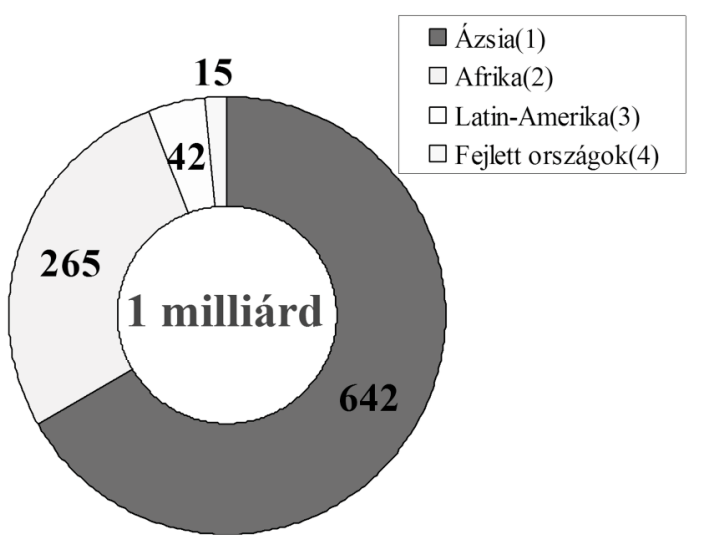

Forrás: ENSZ, 2011 adatok alapján saját szerkesztés

Figure 3: Number of starving people in the world (2010) Asia(1), Africa(2), Latin America(3), Developed countries(4), Source: UN, own edition based on 2011 data

\section{Földhasználat változása}

A világ produktív földterülete folyamatosan változó erőforrás. Az éghajlati változások, a természeti katasztrófák, és az emberi beavatkozás hatására változik. 2002-ben a világ földterületének (150 millió $\left.\mathrm{km}^{2}\right)$ $38 \%$-a volt alkalmas mezőgazdasági tevékenységre, ami azonban folyamatosan csökken (4. ábra). A mezögazdasági területnek kevesebb, mint 30\%-a szántóföld (1,38 milliárd ha). Az egy före eső szántóterület jelentősen csökken (5. ábra), ennek okai: művelhető földeket tesz tönkre az erózió, a túlöntözés miatti szikesedés, egyre terjeszkedő városok és a szántóföldek helyén keletkező utak, bevásárló központok és parkolók építése. A becslések szerint 7,8 hektár termőtalaj vész el percenként.

Magyarországon a rendszerváltás idejére az 1950-es évek időszakához viszonyítva - a szántóterület 52\%-ra, a gyep pedig 13\%-ra csökkent. Jelentősen megnövekedett azonban az erdő (18\%), és mintegy kétszeresére nőtt a müvelés alól kivett terület aránya. Az utóbbi területhasználat növekedése egyrészt az infrastruktúra fejlesztésével, valamint a települések által 
elfoglalt terület növekedésével magyarázható. Napjainkra az arányok tovább romlottak, elsősorban a szántóterület csökkenését kell megemlíteni, 2012-ban 46\%-ra zsugorodott a szántóterületek aránya. Hasonlóképpen lecsökkent a gyepterületek nagysága is $(8 \%)$, viszont tovább növekedett az erdöterületek által elfoglalt terület. A legnagyobb mértékü változás a müvelés alól kivett területek arányában van, amely 21\%-ra emelkedett, ami továbbra is az infrastrukturális fejlődés kiszélesedésével magyarázható (6. ábra).

\section{KLÍMAVÁLTOZÁS}

Az élelmiszertermelés alapvető tényezője az éghajlat, melynek hatását az élelmiszerellátást biztonságosabbá tétele érdekében állandóan tanulmányozni kell (Varga-Haszonits, 2005). Az éghajlati tényezőkben (pl. hőmérséklet, csapadék) történő változás és a szélsőséges időjárási jelenségek (szárazság, árvíz, viharok) nagyobb gyakorisága jelentősen befolyásolják a növénytermesztés hozamait. A klímaváltozás ugyanakkor megváltoztathatja a növényi és állati kártevők típusait, elő- fordulási gyakoriságukat, a rendelkezésre álló öntözővíz mennyiségét, valamint a talajerózió súlyosságát (Adams et al., 1998).

4. ábra: A világ mezőgazdasági területének változása (2002-2009)

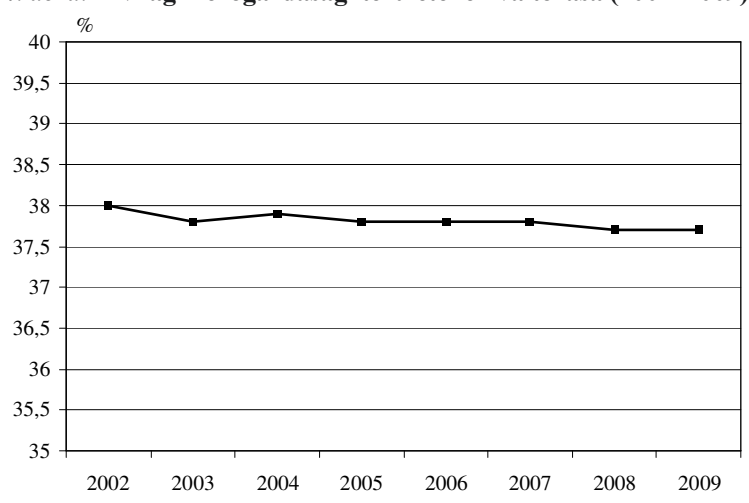

Forrás: CEU-ENS, 2007 adatok alapján saját szerkesztés

Figure 4: Change of the agricultural area in the world (2002-2009) Source: CEU-ENS, own edition based on 2007 data

5. ábra: A világ mezőgazdasági területének változása (2002-2009)

Népesség növekedés(1)

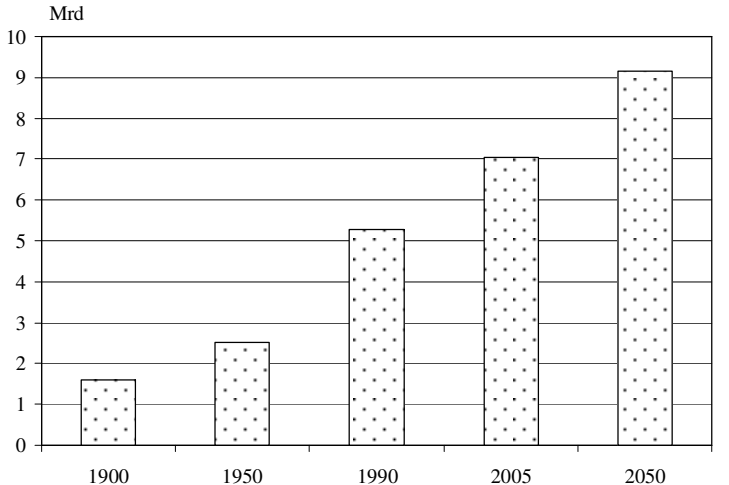

1 fóre jutó szántóterület(2)

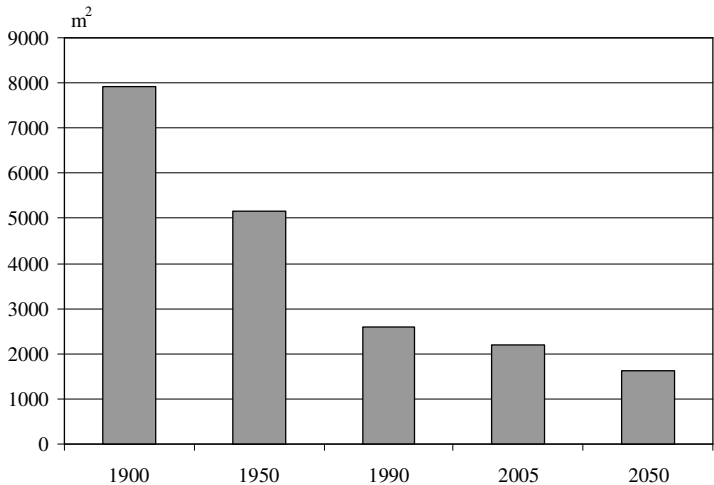

Forrás: CEU-ENS, 2007 adatok alapján saját szerkesztés

Figure 5: Change of the agricultural area in the world (2002-2009)

Source: CEU-ENS, own edition based on 2007 data

6. ábra: Magyarország földhasználat $(1990,2012)$

2012

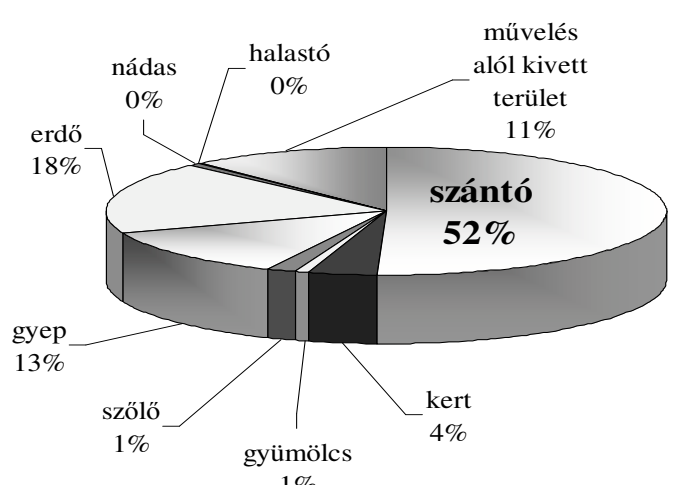

$1 \%$

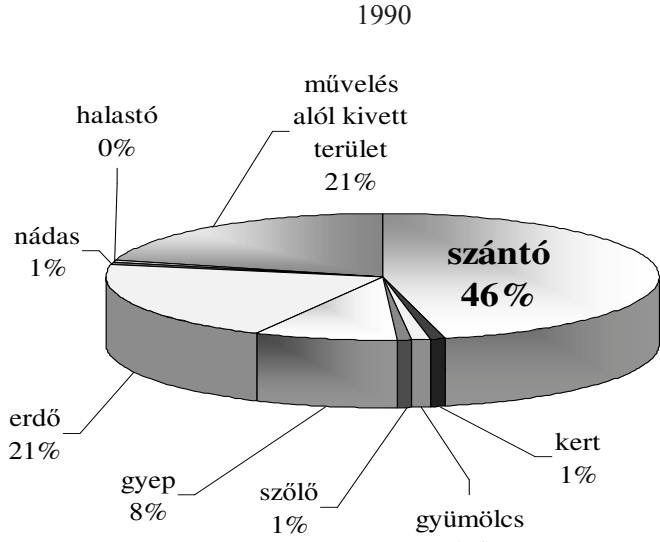

$1 \%$

Forrás: KSH, 1990, 2012 adatok alapján saját szerkesztés

Figure 6: Land use in Hungary (1990, 2012)

Plough-land(1), Garden(2), Orchard(3), Vineyard(4), Grass(5), Forest(6), Reed(7), Fish-pond(8), Areas withdrawn from agricultural production(9), Source: own edition based on CSO data, 1990, 2012 
A levegő földközeli átlaghőmérséklete $0,74 \pm 0,18^{\circ} \mathrm{C}$ kal nőtt a feljegyzések kezdete óta (1890). A legmelegebb évtized világszinten $2000-2009$ volt. A hőmérséklet-emelkedés nem állt meg, az elkövetkező évtizedben 0,10-0,20 Celsius közé tehetö.

A légkörben levő szén-dioxid mennyiségen - becslések szerint - körülbelül 280 milliomod térfogatrész volt az ipari forradalom idején, napjainkban ez 379-re emelkedett. A szén-dioxid emissziója amennyiben ilyen ütemben növekszik, akkor 2015-re a szén-dioxid légköri koncentrációja eléri a kritikusnak tartott 400 milliomod térfogatrészt, egyes modellek szerint ez akár évi $4^{\circ}$ Celsius hömérséklet-emelkedést idézhet elö, a jelenlegihez képest (Bánsági-Domokos, 2009). A globális felmelegedés okozta $0,9^{\circ}$ Celsius hőmérsékletemelkedés ilyen hatással volt Földre, akkor el sem tudjuk képzelni mit eredményezne egy $4^{\circ}$ Celsius emelkedés (1. kép). Haworth (2008) elemzése szerint azonban a felmelegedés nem valószínű, hogy $40{ }^{\circ} \mathrm{C}$-on belül marad - ez kétszerese annak, amit a klíma-katasztrófa elkerüléséhez még biztonságosnak tartanak.

\section{1. kép: A globális klímaváltozás okozta 40 Celsius hőmérséklet-} emelkedés (1890-2015)

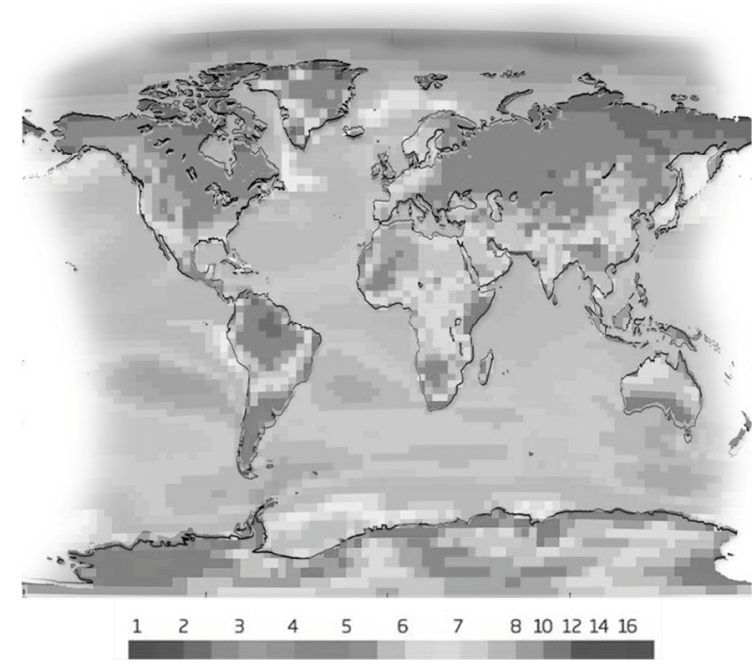

Forrás: Brit Királyi Társaság, 2010

Image 1: 40 Celsius temperature increase caused by climate change (1890-2015)

Source: British Royal Society, 2010

Magyarországon az elmúlt 100 évhez viszonyítva $1{ }^{\circ} \mathrm{C}$-kal nőtt a hőmérséklet, az elörejelzések szerint 2050 -ig további $2,6^{\circ} \mathrm{C}$-kal emelkedik. Jelentősen csökkent az éves csapadék mennyiség is, 640 mm-röl $560 \mathrm{~mm}$ re. A csapadék időbeli eloszlása is egyenetlen. A hőmérsékletváltozás elsősorban az Alföldet sújtja majd a legnagyobb mértékben, és a legnagyobb emelkedés az öszi hónapokban várható (Láng et al., 2007).

A globális felmelegedés következtében a fejlődő országok megmüvelhető földterülete 2015-ig - elörejelzések szerint - 11\%-kal csökkenne, és mintegy 280 millió tonnányi potenciális gabonatermést vesztenének el, ami 56 milliárd dollárnyi értékvesztést jelentene. Ezen kívül a szélsőséges időjárás a hozamok csökkentésén keresztül is visszafogná a kínálatot. Az áradások például a még rendelkezésre álló élelmiszerhez való hozzájutást is akadályozzák az infrastruktúra tönkretétele és a jövedelmek csökkenése által. Ugyanakkor a fejlett országok a klíma-változás nyertesei lennének, mivel északabbra fekvő területeket is művelés alá tudnának vonni Észak-Amerikában, Észak-Európában, Oroszországban és Kelet-Ázsiában. Összességében a klímaváltozás nem eredményezne jelentős gabona-árnövekedést. Ugyanakkor a fejlődő országok - s közülük is a legszegényebbek - nem fogják tudni a termeléskiesés okozta kínálatcsökkenést élelmiszerimporttal ellensúlyozni, ezért nőni fog az elégtelenül tápláltak és éhezők száma (CEU-ENS, 2007).

\section{VÍZGAZDÁLKODÁS, ÖNTÖZÉS}

A globális felmelegedés szárazságot, a szárazság pedig párolgást okoz, ami a Föld vízkészleteinek jelentős hányadát csökkenti. A Föld teljes vízkészlete 2 milliárd köbkilométer. A vízkészlet 97,5\%-a sós és 2,5\% édesvíz. Hasznosítani csak a csapadék formájában a szárazföldre lehulló mennyiséget lehet, azonban a csapadék mennyisége globális átlagban csupán évi $6000 \mathrm{~m}^{3} /$ fós és ennek is csak egy része hasznosítható, évente $2000 \mathrm{~m}^{3} / \mathrm{fó}^{\prime \prime}$. Ez a mennyiség egy ember éves vízigényének kétszerese (Somlyódi, 2011). A népesedés, a klímaváltozás és a gazdasági fejlődés következtében nő a vízigény. Kínának és Indiának például 2-3-szorosára nőhet a vízigénye, jelenleg évi átlagban $700 \mathrm{~m}^{3} / \mathrm{fö}^{\prime \prime}$.

A WHO (2010) szerint 1,2 milliárd ember nem jut megfelelő ivóvízhez. Az egy főre jutó ivóvízkészlet a következő két évtizedben a harmadára csökken. Az UNESCO (2010) szerint, ha a jelenlegi trendek (drasztikus klíma- és ökológiai változások, népesség-növekedés, nagyfokú urbanizáció) folytatódnak, 2050-ben legalább 48 országban több mint kétmilliárd ember komoly vízkorlátozással lesz kénytelen szembenézni.

Magyarországra évente átlagosan $114 \mathrm{~km}^{3}$ víz érkezik, évi csapadék mennyisége pedig $58 \mathrm{~km}^{3}$. Azaz átlagosan mintegy 600 milliméter csapadék esik egy évben. $52 \mathrm{~km}^{3}$ elpárolog, illetve beszivárog, így évente $120 \mathrm{~km}^{3}$ vízmennyiség távozik. A csapadék eloszlása egyenetlen, az ország keleti felére általában kevesebb jut, ráadásul az Alföld déli részén, ahol a napsütéses órák száma magasabb az országos átlagnál, a párolgás és a csapadék hányadosa eléri a másfelet is. Ez növeli az aszály előfordulási valószínüségét, amely általában 3-5 évente fordul elő Magyarországon.

Az 1 lakosra jutó számított vízkészlete $598(600) \mathrm{m}^{3}$ Magyarországon, az éves édesvíz felhasználás $612 \mathrm{~m}^{3} / \mathrm{fo}$. Ez több mint az éves megújítható készlet $\left(598 \mathrm{~m}^{3}\right)$. A különbséget az ország a felszín alatti vizekből szerzi.

A mezőgazdasági vízfelhasználás a világ vízfelhasználásának közel háromnegyedét teszi ki. Ez a 2000-es évben közel 7200 köbkilométernyi vizet jelentett a világon.

A világ növekvő népessége számára egyre több élelmiszer, ennek megtermeléséhez pedig még több öntözésre van szükség így könnyen lehet, hogy 2050-re a világ mezőgazdasági vízfogyasztása elérheti az évi 13 ezer köbkilométert is. Ennek elkerülése érdekében a mezőgazdasági technológiák átalakításra van szükség (vízmegtartó talajművelés, szárazságtürő fajták/hibridek termesztése, precíziós öntözési módszerek alkalmazása stb.). 
A világ öntözött területe 1950-ben 94 millió ha volt, ami folyamatosan nőtt. 2009-re elérte 310 millió hektárt (7. ábra), aminek csupán $17 \%$-a gabonaföld, de a világon elöállított gabona csaknem $32 \%$-át biztosítja. Az öntözött területek nagysága Ázsiában 2009-ben elérte a világ öntözött területeinek 73\%-át, Észak-Amerikában 10\%-át és Európában 7,2\%-át (1. táblázat).

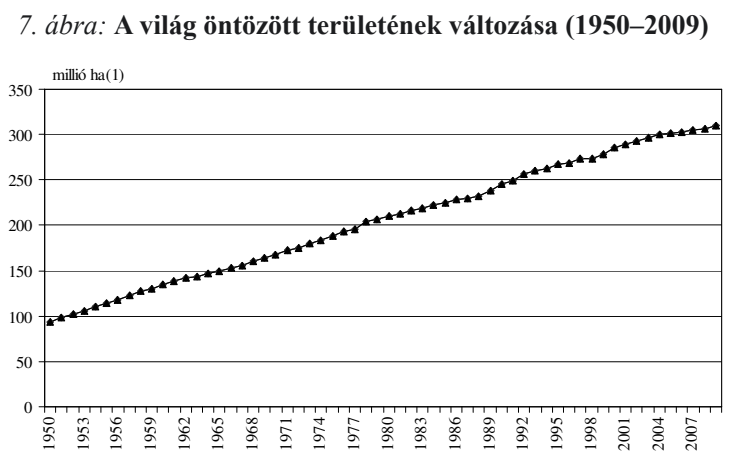

Forrás: FAOSTAT, 1950-2010 adatok alapján saját szerkesztés

Figure 7: Change of the irrigated areas in the world (1950-2009) Million ha(1), Source: own edition based on FAOSTAT data (1950 2010)

1. táblázat

Az öntözött területek változása a világon (millió ha, 2009)

\begin{tabular}{lrrrr}
\hline \multirow{2}{*}{ Kontinens(1) } & \multicolumn{4}{c}{ Öntözött területek (millió ha)(2) } \\
\cline { 2 - 5 } & \multicolumn{1}{c}{1980} & 1990 & 2003 & 2009 \\
\hline Világ(3) & 193,0 & 224,2 & 277,1 & 3044 \\
Afrika(4) & 9,5 & 11.2 & 13,4 & 13,4 \\
Ázsia(5) & 132,4 & 155,0 & 193,9 & 222,2 \\
Latin-Amerika(6) & 12,7 & 15,5 & 17,3 & 10,4 \\
Karib-tenger térsége(7) & 1,1 & 1,3 & 1,3 & 1,7 \\
Észak-Amerika(8) & 21,1 & 21,6 & 23,2 & 31,8 \\
Óceánia(9) & 1,7 & 2,1 & 2,8 & 2,8 \\
Európa(10) & 14,5 & 17,4 & 25,2 & 21,8 \\
\hline
\end{tabular}

Forrás: FAOSTAT, 2009 adatok alapján saját szerkesztés

Table 1: Change of the irrigated areas in the world (million ha, 2009)

Continents(1), Irrigated areas, million ha(2), World(3), Africa(4), Asia(5), Latin America(6), Caribbean(7) North America(8), Oceania(9), Europe(10), Source: own edition based on FAOSTAT data, 2009

Az öntözés intenzitása a különböző országokban függ az éghajlattól, a termesztett növényektől és a gazdálkodási módszerektől. Az öntözés teljesen különbözik a dél-európai országokban, ahol az öntözés elengedhetetlen a mezőgazdasági termelésben, szemben a Közép-és Nyugat-Európától. Az EU teljes öntözött területének nagy része Görögországban (83\%), Spanyolországban (68\%), Cipruson (69\%), Olaszországban (57\%), Franciaországban (54\%) és Portugáliában (52\%) található (Berbel et al., 2007).

Magyarországon a mezőgazdasági terület mindössze 2,1\%-a öntözött (8.ábra). Teljes mezőgazdasági területen csapadékgazdálkodás állítja elő a növényi biomassza jelentősebb részét és az öntözés statisztikailag és ökológiailag is kiegészítő vízpótló erőforrás jellegü Magyarországon. Magyarországon a vízpótló (ökológiai talajnedvesség igény kielégítése a cél) ökológiai öntözés a gazdaságos.
8. ábra: Magyarország öntözött mezőgazdasági területeinek alakulása (1994-2009)

mg.terület, ha(1)

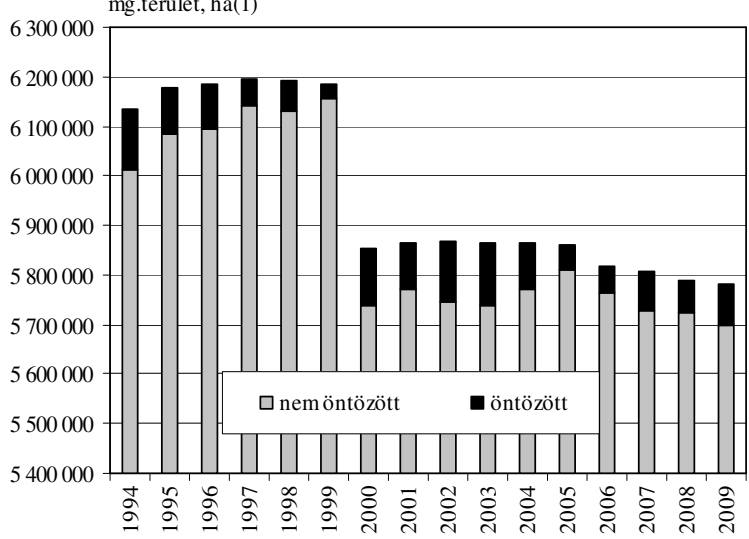

Forrás: KSH, 1994-2009 adatok alapján saját szerkesztés

Figure 8: Irrigated agricultural areas in Hungary (1994-2009) Agricultural area(1), Source: own edition based on CSO data, 19942009

\section{MÜTRÁGYÁZÁS}

A globális problémák, mint a Föld népességének növekedése, szegénység, az élelmiszertermelés lassú ütemü növekedése, környezetszennyezés, stb. - fokozott figyelmet kell fordítani a növénytermesztés fenntarthatóságára különös tekintettel a mütrágyák és növényvédőszerek használatára. Az elkövetkező évtizedekben törekedni kell a gabona- és élelmiszertermelés folyamatos emelésére. A mütrágyák ennek a folyamatnak elengedhetetlen alapanyagai.

A Föld élelmiszer termelésének több mint 40\%-át mütrágya felhasználásával állítják elö. Az összes legyártott tápanyagnak 50\%-át a gabonák termesztése során alkalmazzák, de gyümölcsök, zöldségek és az olajnövények is jelentős felvevőpiacot jelentenek.

Az 1950-ben a világ műtrágya-felhasználása 14 millió tonna volt. A „Zöld forradalom” időszakában 131 millió tonnára emelkedett a felhasználás, vagyis ez az intenzív mütrágya felhasználás időszaka volt, majd az 1990-es évek elején csökkent (9. ábra). Az utóbbi időszakot vizsgálva (2007-2012) a világ mütrágya felhasználása évente 2,6\%-kal növekedett, amely a növekmény mintegy 19,3 millió tonna. A növekedés 69\%-a Ázsiában és 19\%-a Amerikában volt (2. táblázat).

A nitrogénmütrágya évi kereslet növekedése mintegy 2,6\% volt, ami összességében 11 millió tonna. A világ legnagyobb nitrogén importőre Észak-Amerika (7 millió tonna). Nyugat-Európában nem volt növekedés, míg Kelet-Ázsiában volt a világ leggyorsabb növekedése, közel 5\% évente. Latin-Amerika, KeletEurópa és Közép-Ázsia globális felhasználása szerény a relatív hozzájárulásuk - becslések szerint - növekedni fog (10. ábra).

A foszfát mütrágyák éves növekedési rátája körülbelül 2,7\%, ami 5,0 millió tonna. Ázsiában 58\%-os, Amerikában 21\%-os a növekedés. A legnagyobb felhasználók Kelet-Ázsia, Dél-Ázsia és Észak- Amerika. Fontosabb importőrök, Dél-Ázsia, Latin-Amerika és Nyugat-Európa. A felhasználás növekedéséhez a leg- 
nagyobb mértékben Dél-Ázsia (30,3\%), Kelet-Ázsia (24,9\%) és Latin Amerika (24,0\%) járultak hozzá.

9. ábra: A világ mütrágya-felhasználásának alakulása (1950-2009)

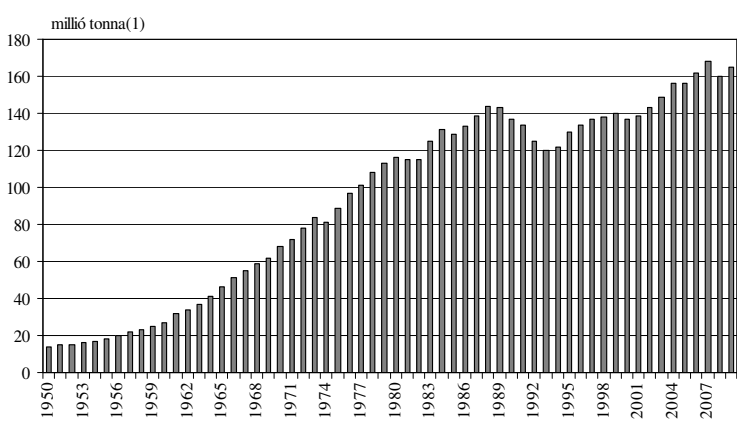

Forrás: FAOSTAT, 1950-2009 adatok alapján saját szerkesztés

Figure 9: Fertiliser use in the world (1950-2009) Source: own edition based on FAOSTAT data, 1950-2009

2. táblázat A világ mütrágya-felhasználásának átlagos évi növekedési üteme (2007-2012)

\begin{tabular}{lccc}
\hline & \multicolumn{3}{c}{$\begin{array}{c}\text { Mütrágya-felhasználás } \\
\text { növekedés üteme }(\%)(1)\end{array}$} \\
\cline { 2 - 4 } & $\mathrm{N}$ & $\mathrm{P}_{2} \mathrm{O}_{5}$ & $\mathrm{~K}_{2} \mathrm{O}$ \\
\hline Afrika(2) & 4,5 & 3,1 & 2,0 \\
Amerika(3) & 1,3 & 3,7 & 2,3 \\
Észak-Amerika(4) & 0,7 & 2,6 & 1,0 \\
Latin-Amerika(5) & 2,5 & 4,6 & 3,5 \\
Ázsia(6) & 3,1 & 2,8 & 3,8 \\
Nyugat-Ázsia(7) & 4,5 & 1,5 & 2,3 \\
Dél-Ázsia(8) & 3,3 & 4,9 & 5,9 \\
Kelet-Ázsia(9) & 2,8 & 1,9 & 3,2 \\
Európa(10) & 0,4 & $-0,2$ & $-0,1$ \\
Közép-Európa(11) & 2,6 & 1,5 & 1,8 \\
Nyugat-Európa(12) & $-0,3$ & $-1,0$ & $-0,7$ \\
Kelet-Európa és Közép-Ázsia(13) & 5,7 & 6,1 & 3,5 \\
Óceánia(14) & 2,0 & 1,0 & 0,6 \\
\hline Világ(15) & 2,6 & 2,8 & 2,7 \\
\hline
\end{tabular}

Forrás: FAOSTAT, 2007-2012 adatok alapján saját szerkesztés

Table 2: Average yearly growth rate of the fertiliser use in the world (2007-2012)

Growth rate of fertiliser use, \%(1), Africa(2), America(3), North America(4), Latin America(5), Asia(6), West Asia(7), South Asia(8), East Asia(9), Europe(10), Central Europe(11), Western Europe(12), Eastern Europe and Central Asia(13), Oceania(14), World(15), Source: own edition based on FAOSTAT data, 2007-2012

A kálium mütrágyák felhasználása 2,7\%-kal nőtt, ami 3,5 millió tonnát eredményezett. Legnagyobb mértékü volt a növekedés Kelet-Ázsiában $(41,0 \%)$ és DélÁzsiában (23,7\%), valamint Latin-Amerikában (23,2\%).

Magyarországon az egy hektár mezőgazdasági területre jutó mütrágya-felhasználás a hetvenes évek közepén volt a legmagasabb, a kilencvenes évek elején ennek kevesebb mint fele, az ezredfordulón pedig a harmadánál is kevesebb. Azóta újra lassan emelkedik a kiszórt mütrágyamennyiség, 2011-ben 77 kg volt (11. ábra).
10. ábra: Részesedés a világ nitrogén felhasználásából (2007-2012)

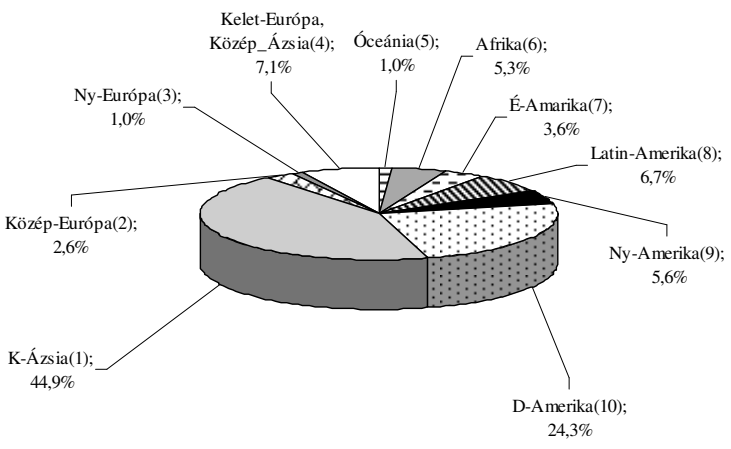

Forrás: FAOSTAT, 2007-2012 adatok alapján saját szerkesztés

Figure 10: Share from the nitrogen use in the world (2007-2012) East Asia(1), Central Europe(2), Western Europe(3), Eastern Europe, Central Asia(4), Oceania(5), Africa(6), North America(7), Latin America(8), West America(9), South America(10), Source: own edition based on FAOSTAT data, 2007-2012

11. ábra: Magyarország mütrágya-felhasználásának alakulása (1950-2011)

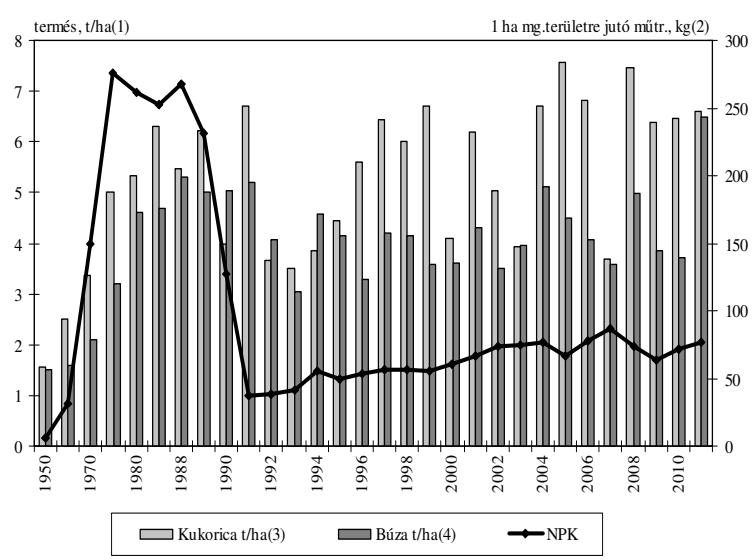

Forrás: KSH, 1950-2011 adatok alapján saját szerkesztés

Figure 11: Fertiliser use in Hungary (1950-2011) Yield, $\mathrm{tha}^{-1}(1)$, Amount of fertiliser $(\mathrm{kg})$ per 1 ha agricultural area(2), Maize, $t_{\text {ha }}^{-1}(3)$, Wheat, $t^{-1} a^{-1}(4)$, Source: own edition based on CSO data, 1950-2011

Magyarországon az 1 ha-ra jutó mütrágya mennyisége Európa szinten viszonylag alacsonynak mondható, és a nitrogén mütrágyák használatának túlsúlya tapasztalható. 2010-ben 73\% volt (12. ábra). A pénzügyi nehézségek miatt elsősorban a foszfor és a kálium kijuttatását csökkentik a gazdálkodók.

A mütrágyatermelés azon kívül, hogy energiát igényel, energiát is termel. Az ásványi mütrágyák növelik a termést, ezáltal többlet biomassza képződik, amely többlet napenergiát köt meg. Amennyiben ezt a koncentrált energiát részben élelem vagy takarmány előállítására fordítják, kalóriává alakul át, így pozitív irányba befolyásolva a mezőgazdaság energiamérlegét. Bár az energia-kibocsátásban nagy különbségek vannak az egyes növényfajok, illetve a termesztési körülmények között, mégis ásványi mütrágyák egy új és egyre nagyobb fontosságú szereppel bírnak a globális energiaigény kielégítésében. 
12. ábra: Magyarország mezőgazdasági területére kijuttatott mủtrágya mennyiségek aránya (1990-2010)

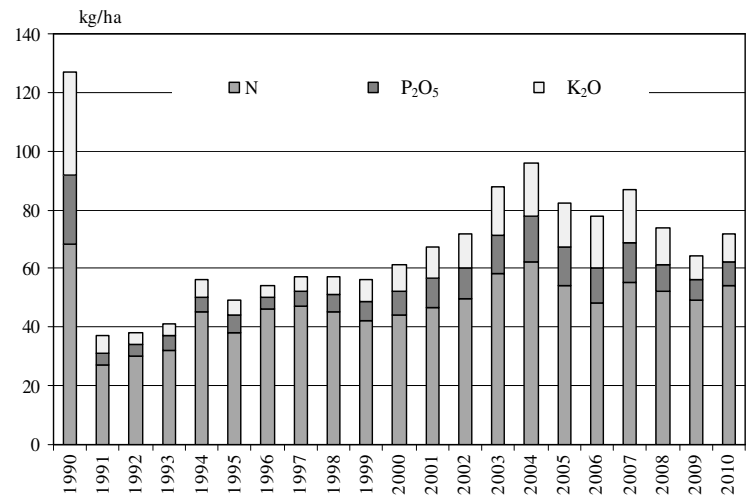

Forrás: KSH, 1990-2010 adatok alapján saját szerkesztés

Figure 12: Ratio of fertiliser applied on the agricultural area in Hungary (1990-2010)

Source: own edition based on CSO data, 1990-2010

\section{NÖVÉNYVÉDELEM}

Az elmúlt évtizedekben a növénytermesztés egyik legfontosabb tényezője a növényvédőszerek használata, amelyek védik növényeket a rovarok és kórokozók ellen, amelyek károsak lehetnek a termés minőségére és a hozamra. Már az 1940-es években számos kis-és közepes jövedelmű országban széles körben használták (Net1). Majd az elmúlt 60 évben világszerte jelentősen megnőtt iránta a kereslet, és jelenleg közel 2,3 millió tonna ipari növényvédőszert használnak évente.
A növénytermelés folyik a gazdaságilag hátrányos helyzetü területeken is, ahol hiányzik a szabályozás és nem érvényesülnek az egészségügyi elöírások. Ezen okok miatt a növényvédőszereket gyakran nem megfelelően használják és tárolják, ezen kívül folyamatos problémát jelent a tiltott növényvédő szerek alkalmazása (Wesseling, 1997).

A világpiaci kereslet éves növekedési üteme a gabonaféléknél 1970-es években 2,5\%-kal az 1980-as években $1,9 \%$-kal és a 1990 -es években $1 \%$-kal csökkent. A táplálkozás és takarmány célú gabona felhasználás az 1980-as években a 334 kg-os szinten tetőzött, és azóta csökkent ( $317 \mathrm{~kg}$ ). 2015-ig a növekedés üteme 1,4\%-ra tehetö. 2015-2030 időszak alatt az élelmiszerfogyasztás számos országban (a lassúbb népességnövekedés miatt) visszafogja a kereslet, így a növekedés várhatóan lassul, 1,2 százalékkal egy év alatt. 2030-ra, extra milliárd tonna gabonára lesz szükség minden évben. Elöre nem látható események, mint például az olajárak drámai növekedése vagy a válságok természetesen befolyásolhatják a hatékony keresletet egy rövidebb időszakokra, de nem fogja jelentősen megváltoztatni.

\section{VÉGSZÓ}

Az éhínség és a nélkülözés az emberiség egy részének mindennapos problémája. Nem véletlen Lowdermilk (1948) borúlátó megállapítása, mely szerint ,az emberiség versenyt fut az éhezéssel már 7000 éve, de nem tudni ki lesz a gyöztes".

\section{IRODALOM}

Adams, R. M.--Hurd, B. H.--Lenhart, S.-Leary, N. (1998): Effects of global climate change on agriculture: an interpretative review. Climate Research. 11: 19-30.

Bánsági É.-Domokos K. (2009): A klímaváltozás tíz meglepő következménye. http://www.origo.hu/tudomany/20070816-klimavaltozas-tiz-meglepo-kovetkezmeny.html 2009-12-1

Berbel, J.-Calatrava, J.-Garrido, A. (2007): Water Pricing and Irrigation: A Review of the European Experience. [In: Molle, F.-Berkoff, J. (eds). Irrigation Water Pricing: The Gap Between Theory and Practice.] CABI: Oxford.

Brit Királyi Társaság (2010): Négy fokkal melegszik fel a Föld 2060ra. http://www.hir24.hu/tudomany/2010/11/30/negy-fokkalmelegszik-fel-a-fold-2060-ra/

CEU-ENS (2007): A globális környezet középtávú gazdasági előrejelzése. A világ mezőgazdasága és az agrártermékek világkereskedelme (WTO). MTA Világgazdasági Kutatóintézet. Budapest.1-15.

ENSZ (2006): World Population Growth, 1950-050. http://www. census.gov/population/international/data

ENSZ (2011): Egy milliárd ember éhezik. http://www.origo.hu/ nagyvilag/20100430-fao-ensz-egymilliard-ember-ehezik.html

FAOSTAT (1900-2012): http://faostat.fao.org/
Haworth J. (2008): A globális felmelegedés okozta hőmérséklet emelkedés a 'biztonságos határ kétszerese lesz' http://www.globalisfelmelegedes.info/index.php?option $=$ com_content\&task=vie w\&id $=251 \&$ Itemid $=51$

KSH Statisztikai évkönyvek (1950-2012)

Láng I.-Jolánkai M.-Csete L. (2007): A globális klíma változás hazai hatások és válaszok - A VAHAVA jelentés. Szaktudás Kiadó Ház Rt. Budapest.

Lowdermik, W. C. (1948): Civilisation's Race with Famine, The Listener, 1948. apr. 15. Royal Ministry of Agriculture: NonTrade Concerns in a Multifunkctional Agriculture - Implications for Agricultural Policy and the Multilateral Trading System. 1998.

Net1: http://www.fao.org/ag/save-and-grow/.

Somlyódi L. (2011): Vízdilemma a világban és Magyarországon. MTA Hírlevél, http://mta.hu/tudomany_hirei/vizdilemma-avilagban-es-magyarorszagon-126876/

Varha-Haszonits Z. (2005): Az éghajlat változékonysága és az agroökoszisztémák. Agro-21 füzetek. 41: 29-37.

Wesseling, C. (1997): Agricultural Pesticide Use in Developing Countries: Health Effects and Research Needs. International Journal of Health Services. 27. 2: 273-308.

WHO, UNESCO (2010): A víz világnapja - március 22. http://antalvali.com/hirek/a-viz-vilagnapja.html 
